\title{
Pulmonary actinomycosis with large cavitation in an alcoholic 39-year-old man
}

\author{
A Sénéchal, ${ }^{1}$ F Valour, ${ }^{1,2,3}$ C Chidiac, ${ }^{1,2,3}$ T Ferry $^{1,2,3}$
}

${ }^{1}$ Service de Maladies Infectieuses et Tropicales, Hôpital de la Croix-Rousse, Hospices Civils de Lyon, Lyon, France

${ }^{2}$ Université Claude Bernard Lyon 1, Lyon, France

${ }^{3}$ Centre International de Recherche en Infectiologie (CIRI), Inserm U1111, CNRS UMR5308,

ENS de Lyon, Lyon, France

\section{Correspondence to} Dr T Ferry,

tristan.ferry@univ-lyon1.fr

Accepted 30 October 2014
CrossMark

To cite: Sénéchal $A$, Valour F, Chidiac C, et al. BMJ Case Rep Published online: [please include Day Month Year] doi:10.1136/ bcr-2014-206556

\section{DESCRIPTION}

A 39-year-old man with a history of alcohol and tobacco abuse was admitted after experiencing 1 month of productive cough, night sweats, mild dyspnoea and weight loss. Physical examination revealed alteration of general state $(45 \mathrm{~kg}$, loss of $15 \mathrm{~kg}$ ), mild fever $\left(38^{\circ} \mathrm{C}\right)$ and low oxygen saturation (88\%). HIV serology testing was negative. Chest X-ray and CT scan showed right upper lobe cavitation (figure 1A, B). Bronchoalveolar lavage (BAL) was performed and piperacillin/tazobactam was started. Direct examination and culture of respiratory samples were both negative for tuberculosis. Actinomyces spp was found in BAL and sputum samples. Treatment was changed to high doses of intravenous amoxicillin. Stomatological examination revealed apical lesion of teeth 16 and 28, which were removed. Six weeks after first admission to hospital, the patient had a favorable outcome with weight gain, fever clearance, regression of inflammatory syndrome and radiological improvement (figure 1C). Treatment was changed to oral therapy with amoxicillin for 4 months. The outcome was favourable.

Pulmonary actinomycosis is frequently associated with poor dental hygiene, dental diseases and alcoholism. A primary focal lung involvement following osopharyngeal secretion could mimic malignancy, especially as it is usually associated with general symptoms such as weight loss. The lesion can invade adjacent tissue and cavitation may also occur. ${ }^{12}$ BAL is of importance to exclude tuberculosis and incubation of at least 10 days in enriched media is required for the bacterial diagnosis of actinomycosis. At least 3 months of amoxicillin in high doses remains the treatment of choice in pulmonary actinomycosis. ${ }^{3}$

\section{Learning points}

Pulmonary actinomycosis is frequently associated with poor dental hygiene, dental diseases and alcoholism.

- Pulmonary actinomycosis can mimic lung cancer or tuberculosis.

- At least 3 months of amoxicillin in high doses remains the treatment of choice in pulmonary actinomycosis.

Contributors AS wrote the case. FV, CC and TF performed a literature review and wrote the process.

Competing interests None.

Patient consent Obtained.

Provenance and peer review Not commissioned; externally peer reviewed.

\section{REFERENCES}

1 Valour F, Sénéchal A, Dupieux C, et al. Actinomycosis: etiology, clinical features, diagnosis, treatment and management. Infect Drug Resist 2014:183-97.

2 Cheon JE, Im JG, Kim MY, et al. Thoracic actinomycosis: CT findings. Radiology 1998;209:229-33.

3 Kolditz M, Bickhardt J, Matthiessen W, et al. Medical management of pulmonary actinomycosis: data from 49 consecutive cases. J Antimicrob Chemother 2009;63:839-41.
Figure 1 Right upper lobe cavitation ((A) chest X-ray and (B) CT scan) in a patient with pulmonary actinomycosis. Improvement was noticed after antimicrobial therapy ((C) CT scan).

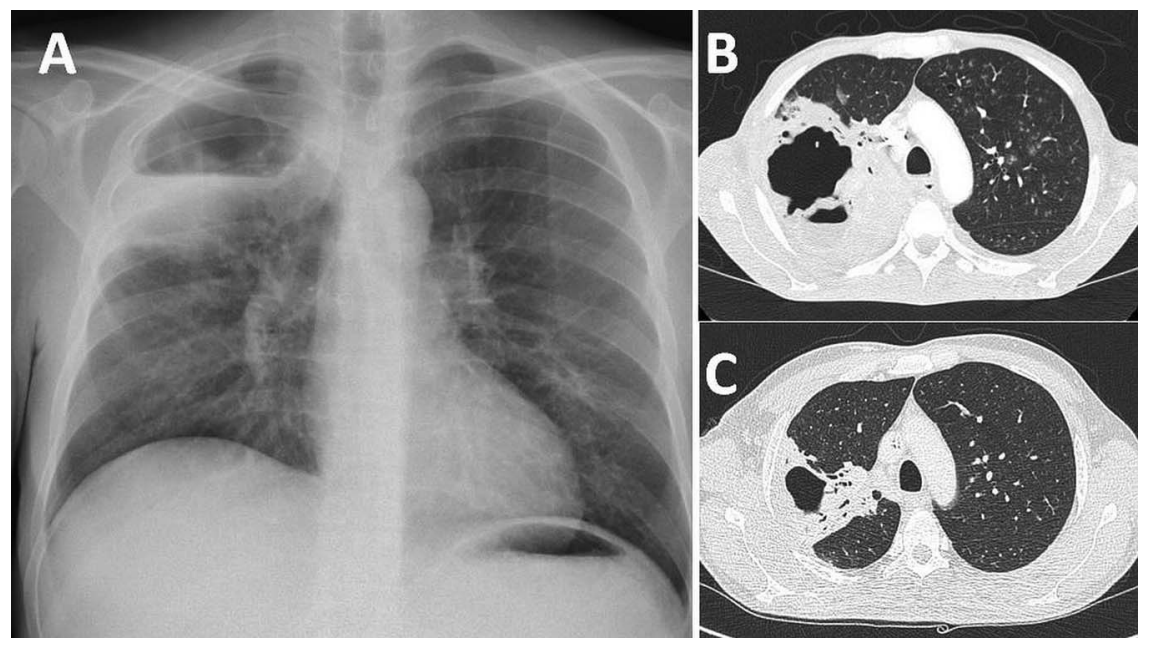


Copyright 2014 BMJ Publishing Group. All rights reserved. For permission to reuse any of this content visit http://group.bmj.com/group/rights-licensing/permissions.

BMJ Case Report Fellows may re-use this article for personal use and teaching without any further permission.

Become a Fellow of BMJ Case Reports today and you can:

- Submit as many cases as you like

- Enjoy fast sympathetic peer review and rapid publication of accepted articles

- Access all the published articles

- Re-use any of the published material for personal use and teaching without further permission

For information on Institutional Fellowships contact consortiasales@bmjgroup.com

Visit casereports.bmj.com for more articles like this and to become a Fellow 